\title{
Orfeu Mestiço: Território conquistado do latifúndio-indústria cultural
}

"A vontade era dar mais um passo dentro da linguagem do teatro hip-hop através da criação de uma hip-hópera". Assim a diretora e dramaturga do Núcleo Bartolomeu de Depoimentos, Claudia Schapira, inicia seu depoimento no programa do espetáculo Orfeu Mestiço - Uma Hip-Hópera Brasileira.

Um novo passo pode ser dado como avanço em linha reta, pode significar mais um desvio sobre traçado já irregular, pode arriscar-se em abismo. Numa primeira visada, Orfeu Mestiço é passo avante na linguagem do grupo, o teatro hip-hop, sobre o qual falaremos mais adiante e, ao mesmo tempo, no que diz respeito à pesquisa temática, passo atrás sobre rastro alheio, investigação de um caminho percorrido por outra geração. Na recriação do Núcleo Bartolomeu para o mito de Orfeu - o mortal que desce aos infernos para resgatar sua amada, obtém êxito, mas falha no caminho de volta por olhar para trás, e novamente perde sua Eurídice - a trama é detonada pela exumação do corpo de uma militante política brasileira desaparecida na década de 1970, torturada e morta pelas forças de repressão do governo militar, no poder de 1964 a 1985. Orfeu, ex-parceiro no amor e na militância, agora membro da Suprema Corte, revisita seu passado. Com esse ponto de partida o grupo convoca o espectador a entrar inteiro - corpo e mente; sentidos, sentimentos e razão - no barco/espetáculo que trafega pela história recente do país.

Por que esse movimento ora sobre e ora sob rastros? A escolha, evidentemente não casual, de um mito amoroso e de retorno a um tempo em que uma utopia vinculava pessoas, permite traçar as grandes linhas de força da história a partir de trilhas individuais entrelaçadas por transmissões de afetos ou cindidas por instâncias de poder econômico e político. Não é pequena a ambição que move o grupo na criação dessa montagem: refazer a trama dos fios tecidos para formar o que chamamos de nação brasileira, desejo que se pode detectar já na citação do moçambicano Mia Couto na abertura 
do texto assinado por Schapira: "... a janela: não é o lugar onde a casa sonha ser mundo?" Sobre o êxito do desejo nessa empreitada - para a qual convergem dramaturgia, atuações e recursos cênicos de um coletivo de artistas experientes e amadurecidos em sua linguagem, o teatro hip-hop, que vem sendo forjada há treze anos - tentaremos falar ao longo deste artigo. Por ora fiquemos com o que impulsiona esse movimento.

Um fio atado no passado pode ser desatado no presente? Mais ainda, pode ser reatado e tecido em outra trama no futuro? É possível desatar nós sem que o tecido se rompa? Tais questões encorajam o grupo pela travessia por águas revoltas, a eterna descida ao inferno das incertezas, que é o processo de criação de um espetáculo.

O primeiro procedimento bem sucedido é o de imprimir a Orfeu e Eurídice caráter de exemplaridade. Assim são moldados como indivíduos - com seus desejos, contradições e afetos - e como sujeitos coletivos. Ela, de ancestralidade índia e cabocla, vem daquela imensa parcela da população que desde as capitanias hereditárias vive em luta cotidiana pelo pão, a 'classe perigosa' para os detentores do poder, pois pode explodir em revolta, com pouco a perder. Orfeu, 'afilhado' de um coronel-latifundiário, é o jovem de classe média, seduzido pela causa, (do movimento voraz/sinto o chamado), estudante de direito (a voz como instrumentole o estudo pano-de-frente/ do levante o estandarte). Informações que chegam ao espectador na forma de canto - as párias, como o grupo define as árias dessa hip-hópera -, em versos de potente síntese poética, qualidade que perpassa toda a dramaturgia, revelando em Schapira uma autora de talento lapidado pelo tempo em exercício. Ambos, Orfeu e Eurídice, partilham do imaginário coletivo de sua época e vislumbram a possibilidade de tomar o poder do "jeito-revolução" (somos povo, somos fogo!/Mestiça e não submissa/ se precisar, instrumento-morte na mão), canta Eurídice, ainda que ela também maneje as armas do pensamento-argumento, militando como professora.

O encontro entre eles está entre as muitas cenas desse espetáculo reveladoras da capacidade do grupo de criar amplas cartografias com poucos traços, por meio de fusões cênicas precisas. Orfeu e Eurídice são 'apresentados' um ao outro, e ao público, na forma de depoimento rimado e ritmado - elemento essencial à cultura hip-hop - que a um só tempo define o perfil de ambos e remete ao palanque estudantil, aos festivais da canção e às manifestações de rua. Se o presente artigo não consegue dar conta de toda a paisagem visual e sonora da cena, vale, entretanto, reproduzir uns poucos versos do discurso/apresentação de Eurídice: Eu, Eurídice/Eu, braço erguido/Eu, resistência e 
perigo/Eu contra muitos e comigo/Eu em árida paisagem/Sonhadora e moça/Eu prenda querida/Eu tão jovem e já ferida/Eu vou... por que não?/. Esta última indagação se funde com a melodia da conhecida canção Alegria, Alegria, defendida por Caetano Veloso num festival da canção, em 1967. Assim o grupo sintetiza uma época e uma ambiência cultural compartilhada por uma parte expressiva da juventude que nela milita.

Seguindo a trilha do mito nessa transposição cênica o Brasil das décadas de 1960 e 1970, indaga-se: qual a falha trágica de Orfeu? Num procedimento chave de desconstrução e reconstrução do mito original, Orfeu igualmente se perde por olhar para trás, porém não para sua parceira de amor e luta. Não é esse o movimento de sua falha, mas uma dívida de afeto com seu padrinho. Um jantar em família provocará a denúncia que levará Eurídice aos porões, onde será torturada até a morte. Na relação entre Orfeu e coronel os fios se ligam em trama trágica. Não há leitura redutora aí, pois o destino individual é também coletivo. Vale a dimensão exemplar do gesto de Orfeu, cuja origem remete à teoria da 'cordialidade' que vela conflitos de interesses e está no cerne da formação da nação brasileira.

A escolha do olhar amoroso sobre a história não implica perda de contundência. Risca-se o chão. Se há militantes duramente torturados, há responsáveis por esse ato hediondo. E são apontados. Mas o espetáculo não se instaura como tribuna política. Antes, busca conduzir o espectador 'a quente' para aquele tempo em que a luta por um mundo mais justo se tornou guerra, na qual muitos entraram pelo campo do simbólico, tendo palavras e palco como armas, e acabaram atingidos em sua carne. Em toda a encenação recursos cênicos se harmonizam ao texto e às interpretações para dar conta de uma nação multifacetada. Véus/cortinas se abrem e se fecham, ora velando, ora revelando camadas, profundidades; a palavra-chave tempo é grafitada com luz sobre véu; cenários surgem inesperados como a catedral que se materializa em luz projetada sobre véu ou ainda a imagem/negociata de poderosos criada - ternos, rostos encobertos, atitude corporal - em síntese de quadrinhos; sonoridades diversas e figuras que vão do cangaceiro/morte, passando pelo guerrilheiro, até entidades da mitologia africana têm presença elaborada para alcançar o feito de valorização de seu lugar na tessitura da nação brasileira.

Porém, no caminho de volta desse percurso bem-sucedido, o grupo parece ter cedido ao desejo de, metaforicamente, resgatar Eurídice, escolha vacilante ao fim de árduo e exitoso percurso. Orfeu adulto faz o que o Orfeu jovem não foi capaz: rompe seu laço com 
o poder, renuncia ao cargo no Supremo Tribunal, e vai juntar-se à jovem militante que vem do movimento dos sem-terra. Há uma contradição nessa ação/transformação de Orfeu. É possível entender claramente o que se aponta aí, a necessidade de 'estar do lado certo da luta,' de buscar os vínculos/parceiros de utopia. Porém ocupar um lugar no staff do coronel - que evidentemente tem vínculos que podem se estender até o judiciário - não configura a mesma relação de poder que ocupar um cargo num Tribunal de Justiça. Afinal, se o passado serve para iluminar o presente, o que se busca nessa mirada rastro atrás não são ações individuais ou mesmo de grupos, mas sim a compreensão da cartografia do poder.

Quais seriam os antagonistas, os 'padrinhos', dos tempos atuais? Tal vislumbre pode ser localizado na cena do desdobramento do jantar na casa do latifundiário. À mesa, o coronel oferece a Orfeu emprego em suas terras/empresa. Eurídice, confiante e altiva, nega, irônica, imaginando que pode falar por Orfeu em estreita parceria. É convidada a sair da sala para ver "a coleção de vestidos" da esposa do coronel. Alijada da conversa por um Orfeu hesitante, Eurídice vê sua estatura subitamente diminuída pela atitude de seu parceiro e assim, reduzida em tamanho, ela entra no país das maravilhas que é o closet cheio de belos vestidos e de empregadas/mucamas de Maria Alice. Em mais uma síntese brilhante, desfilam diante de Eurídice vestidos e personagens da história, uma vez que a dona da casa se transmuta em muitas mulheres, das rainhas Carlota Joaquina e Maria I, a Louca, até a 'madame-perua-Daslu'. Todas proferem, compulsivamente, discursos que são variações sobre o mesmo tema: um profundo desprezo para com o povo mestiço e ignorante, ao qual elas atribuem a culpa pelas mazelas do País. A cena do closet remete a uma frase, mais uma variação sobre o tema, não presente em palavras, mas significação: um bom banho de loja desmonta qualquer militância. E não será essa a estratégia mais eficaz das classes dominantes na atual etapa do capitalismo? Pelo consumo se amansam as classes perigosas? Desde o início, ainda na sala de jantar, o recurso dos pratos que caem da mão dos empregados como efeito de tensão é muito expressivo - a cena se abre em múltiplas camadas, ampliando possibilidades de leitura. E leva a pensar que, seja num Tribunal de Justiça, seja entre militantes do MST, Orfeu ou Orfeus, terão de se deparar com esse vínculo-fetiche-afetivo homem-mercadoria, nó a ser desfeito.

Numa outra cena, mais uma das sínteses muito bem resolvidas dessa montagem, o mesmo coronel defende a posse da terra, de grandes pedaços dela, e a certa altura diz: "entenda por terra o que você quiser, um jornal, por exemplo..." Pois o Núcleo Barto- 
lomeu demonstra que um espetáculo também é terra - "zona autônoma temporária" define o grupo no prólogo - que se conquista, se habita, se cultiva e se compartilha. Durante o tempo efêmero em que dura uma obra teatral instaura-se um pedaço de território dentro do continente que é o imaginário coletivo. Os artistas do Núcleo Bartolomeu têm consciência da importância que é conquistar do 'latifúndio indústria cultural' esse 'território-depoimento cênico'. A utopia é algo que habita o imaginário. E tudo o que chamamos de realidade tem o imaginário coletivo como ponto de partida e de chegada.

Se o grupo demonstra ser potente a atuação no campo do simbólico, não haveria então diferentes e legítimos campos de luta? Não seria um equívoco renunciar à terra? Não é o que o Orfeu adulto faz? O que o espetáculo resgata é a reflexão sobre o que era o cerne da utopia-revolução - o desejo coletivo de um mundo mais justo como dispositivo de transmissão de afetos, construtor de parcerias. Só vale a parceria ombro a ombro? Se Orfeu em vez de voz hesitante for voz atuante no seu lugar de poder não vale? Importante não é saber quais são os nós a serem desatados? Se a análise está correta, ainda assim o equívoco final não invalida a potência do percurso.

Desde seu surgimento, em 1999, não por acaso mesmo ano do lançamento do primeiro manifesto do Movimento Arte contra a Barbárie, um tempo de repolitização da cena teatral após a década de 1980, período no qual predominou a busca formal em encenações 'assinadas' por diretores e não coletivos, os artistas do Núcleo Bartolomeu perseguem a criação da chamada arte engajada. Não por acaso convocam o movimento hip-hop. Instaurado pela junção de diferentes manifestações artísticas surgidas no entorno degradado das grandes metrópoles ${ }^{1}$ - o hip-hop é antes de tudo uma tomada de consciência sobre o lugar que se ocupa numa estrutura de poder. E faz brotar das periferias das grandes metrópoles manifestações artísticas com potência crítica, não representação, mas depoimento pessoal, impresso e expresso no corpo, voz em carne viva. Os artistas do Núcleo Bartolomeu amalgamam essas novas manifestações artísticas à experiência acumulada em séculos de tradição teatral. Assim, em Bartolomeu, o Que Será que Nele Deu?, espetáculo-gênese do grupo, um corifeu/MC faz comentários críticos em ritmo e rima de rappers, recurso épico-brechtiano que incide sobre a estrutura dramática - um conto de Herman Melville, sobre um escriturário que se recusa

\footnotetext{
${ }^{1}$ Considera-se marco zero do Movimento hip-hop a primeira 'festa de quarteirão' (block-party) realizada no bairro do Bronx, em 1973, reunindo DJs (disc-jóqueis), MCs (mestres de cerimônia), rappers, grafiteiros e dançarinos de break. No Brasil, DJs e dançarinos de break realizam encontros a partir da década de 80 , na estação São Bento do metrô paulistano.
} 
a trabalhar em ato de resistência/desistência, transmutado em potência pelo grupo rompendo-a de forma crítica, poética e lúdica. É a força política desse movimento como 'voz do tempo presente' que se convoca naquele momento de gênese do grupo - não por acaso os atores do grupo se autodenominam MCs - para criar essa linguagem híbrida - o teatro hip-hop - que não surge pronta e acabada, não está isenta de contradições e impasses, e vem sendo forjada ao longo dos anos não como 'achado' para a criação de uma escrita cênica singular, mas como expressão de crítica social. É a busca de uma arte com poder de interferência - e os impasses com os quais o grupo se depara ao longo da trajetória - o que une as pontas, Bartolomeu e Orfeu.

Porém a oscilação final, se o ponto de vista está correto, não invalida o percurso do grupo que, evidentemente, não finda nesse ponto de chegada. Novos e bem-vindos passos dentro da linguagem hip-hop certamente serão dados pelo Núcleo Bartolomeu de Depoimentos.

Como lutar e viver? É a indagação que Orfeu Mestiço nos faz com essa escolha dupla de percurso, mito amoroso e retorno a um tempo de utopia. Independentemente de seu passo derradeiro, faz refletir sobre o que era o cerne da utopia-revolução - o desejo coletivo de um mundo mais justo como dispositivo de transmissão de afetos, construtor de parcerias.

\section{Referências bibliográficas}

BARTOLOMEU, Núcleo. Programa da peça Orfeu Mestiço, uma hip-hópera brasileira.

HOLANDA, Sérgio Buarque de. Raízes do Brasil. 26ª edição, 25ª reimpressão. São Paulo: Companhia das Letras, 2006.

NÉSPOLI, Beth. Ciclo do Núcleo Bartolomeu dá voz à juventude da periferia. O Estado de S. Paulo, 3/10/2008, p. D4.

-. Mítica que brota das ruas da cidade. O Estado de S. Paulo, 8/9/2006, p. D5.

-. Hip-Hop atualiza peça do século 17. O Estado de S. Paulo, 9/5/2003, p.D8.

—. Piração num escritório em ritmo de hip-hop. O Estado de S. Paulo, 3/11/2000, p.D5.

SCHAPIRA, Claudia. Bartolomeu, o que será que nele deu? Texto da peça. São Paulo: Centro Cultural São Paulo, Coleção Dramaturgia, 2004.

-. Orfeu Mestiço, uma hip-hópera brasileira. Texto da peça cedido pela autora. 